\title{
XXI. Comparative anatomy; or a slight attempt to draw up a comparison between animal and vegetable life
}

\section{Mrs. Agnes Ibbetson}

To cite this article: Mrs. Agnes Ibbetson (1815) XXI. Comparative anatomy; or a slight attempt to draw up a comparison between animal and vegetable life, Philosophical Magazine Series 1 , 46:208, 81-100, DOI: 10.1080/14786441508638504

To link to this article: http://dx.doi.org/10.1080/14786441508638504

电 Published online: 27 Jul 2009.

Submit your article to this journal $\pi$

ЏII Article views: 2

Q View related articles $₫$ 


\section{$\left[\begin{array}{ll}1 & 8\end{array}\right]$}

XXI. Comparalive Anatomy; or a slight Atlempt to drau ub a Comparison leitueen Aninal and legetalie Life. Dif Mrs. Agnes Inderson.

\section{To Mr. Tilloch.}

Sir, - A FTrR having dissected most parts of vegetables, shown their different powers, and endeavoured as far as able to inyiure into and explain the various uses to which each different part is applied, it struck me that it was now time to draw up something of a comparison between animal and regetable life. I have often during the course of this work lamented the injury done to the anatomy of botany, from comparisons drawn only from human anatomy: because a surgeon would be but too apt to add many more powers than really exist in the vegefable, unless he had very exactly compared and siudied the two dissections tngether. Hut as a perfect assistance may lie procured in the description of the liuman hody, that, joiner? to a thorough knowledge of the vegctable, would not, I think, be liable to the same objection. I shall, however, try it : and if I should make any mistake, it will be pardoned in one who can claim but very imperfect knowledge in human anatomy, and who will (but in a very few cases) attempt (in animal analomy) to horrow from her own dissections.

In reading books of anatomy, and viewing the dissections of aninal life, when contrasied with a vegetable boing; it is impossible not to be strnck with the studied care and chlorate pains seemingly exhansted in forming the first, and she clearness of invention and simplieity of formation observed in the second. 'T', display this, I shall first give a slight sketch of the hmon figure. contrasting it, as $I$ proceed, with a more funched pieture of the vegetable frame; touching most lightly on those parts which almit not of being compared with phants, but dwelling as strongly and clearly as posilile on those featury which do, or are supposed to, admil of some resenblance to the himan structure. In viewing the figure of a man and of a tret, it is bardly possible to conceive two things more completely dissimilar; and in heholding the skeleton of each, they would appear too much $1 ;$ like to be compared, not seeming at a first view to offer any of those similitudes which are necessary in such cases.

But though no general resemblance can be wiseorered, yet a sort of comparison may he drawn up, perhaps admutageous to both, as more clearly impressing on the mind tine beautiful diversity to be found in tw' leings, both possessed of a different kind of existence; showing also a few instances in which there is some resemblance; fixing the similitude which daes or does mot Vol. 46. No. 205. Ausust 1815. F rait; 
exist; but which in contemplation must continually remind us, that the same great and benevolent Being formed and created both.

To give some idea, though an imperfect one, of the nature of the two different beings to be compared, "the human form and vegetable," it is first necessary to fix on those parts which can in any measure be assimilated to each other. To tlie brain, spinal medulla, and heart of an animal, we can only with justice contrast the line of life of a tree. But how different! how inferior! The spiral wire is, however, a more faithful image of the muscle: indeed, as the plant is apparently a mechanical being, we might expect to find the strongest similitude in these parts; and as the musele is in loll the only part which seems to possess a self-existing motion, we can be in no danger of mistaking in the vegetable the wrong situation, since the spiral is the only part which is vis insila. The wood and the bones also have some curious analogies. The blood, with the bark, juice, and sap, may be compared. The oil of the muscles and spiral wire are the sane. The womb and seed-ressel are something alike. The stomach, the place of digestion; the liver, the secreter of bile; the kidneys, the bladder,-all belong to a being that digests; which the plant does not. The skin and the upper cuticle have no resemblance whatever. The plant has no nerves; nor are the muscles at all attached to the Jine of life, or brain of the plant. Both beings have lymphatics, both have glands, but the vegetable is different from the animal gland; since the vegetable has no secretions from the blood, but receives the juices of this kind all pure from the hairs. Does not every part of this selection prove the vegetable to be a mere mechunical agent? a great and bold line, drawn by the Almighty hand to diversify and beautify creation, and fill up the link which would otherwise be wanting between the organized and unorganized matters! Let us then descend to the minutiæ of the existing difference.

First then (to borrow Hunter's words and plan), we must form a human being. The MIND (the immaterial agent) must be provided with a place of immediate residence, which shall have all the requisites for the union of spirit and body: accordingly she is provided with a brain, where she dwells as governor and superintendant of the whole fabric. In the next place, as she is to hold a correspondence with all the material beings around her, she must be stipplied with organs fitted to receive the different kinds of impressions which they will make: in fact, therefore, we see that she is provided with the organs of sense; the eye to see, \&c. \&e, Further, she must be furnished with other organs between herself in the brain and those organs of sense; and she and inave other organs between herself in the brain and every 
a Comparison between Animal and Vegetalle Life.

other part of the lody, fitted to convey her commands and influence over the whole. For both these purposes, nerves are adapted; they convey all the sensations to the mind, and give notice of all sutfering. It is evilent, therefore, that all sensations arise from the impression of some active substance on some nerve of the haman boty; and that the same is represented to the mind by the means of the nerves comneted with the brain: every nerve, therefore, that is irritated produces a sense of pain; and if certain parts of the brain are compressed, from which particular nerves arise, then those senses are losi which depend on those nerves. But in the injuries of the spinal inedulla (which is a continuation of the brain down the vertebre of, the back) this is still more evident; for those parts which receive their nerves arising from the place injured in the meduilu, are either convulsed if that be irritated, or rendered paralytic if that be compressed (and if the greater part of the brain suffers, the whole body loses its power of motion). These things considered, there seems to be no doult that the cause of all sensilility arises from the nerves being connected with the brain or spiual medulla; and that all volumtary motion equally arises from the connexion of the nerves with the muscles, thus conveying its orders to and from the brain. Therefore it eannot reside in the nerves themselves; because otherwise the moving cause would continue to act after being separated from the brain, nor would it be increased by its irritation.

Of all this important and admirable formation of the human body, what part does the vegetalle possess? Scarcely any that can deserve to be assimilated to so wonderful and marvellous a structure of senses and feelings; though it has certainly great beauty, not only from its simplicity, but arising also from the fitness of its forn, so admirably adapted to its situation in the grand scale of beings; but without volition, without sensilility, even without senses. The line of life can only be said to be the lorain, spinal medulla, and heart to the plant, to stand for all three, though it resembles the heart only as the first visible life, and the brain alone as the chief source of existence, and the spinal medulla as passing like the line of life through the body. But how inferior an image of all! It has not the action of the heart, having neither arteries nor blood to circulate; nor the brain, having no nerves. I have entered more minutely into this thars I intended, in order to impress on my reaters a conviction I feel myself, that, thus formed, there can be no volition in plants.

To begin then with the description of the line of life (the only part that can be compared to the brain and spine of an animal), The line is formed of a matter firmer than the bark, not so hard as the wood, generally of a white colour, but sometimes green, 
sometimns yellow, always llack when dead. When a vegetable is really killed, this line is the fir.t part to die: 一thus, when struck with lightning or a hard fro,t, in a noment this line turns llack, and can never arain be revived, though the bark and leaves may for a tine retain their verdure; as, like the hair and nails of ain animal, they porsess but little life. The line of life consists of three or four rows of erlinders hollow in the middle, and within them are generally found the juices of the nertary; but this mixture forned in the middle root, seldom, I believe, flows up the vessels till after the flou er has passed up them: about the end of February the flower (formed in the root) enters these vessels, which enlorge for the purpose, and run up them, till they arrive at the buds, which were empty till then, having only their scales (prepared some time before), and smeared with an oil which protects the interior from all danger. The embryo then quits the vessels, and enters those buds which are properly their cradles in the hark, situated in the axillæ of the leaves. The vessels, after this service done, are restored to their usual size, and remain all tlie rest of the year unaltered, still conveying the nectarcous juices. It is only three weeks of the year that this phænomenon can be seen; it appears in every plant neariy a month before the flowering season. With respect to life, this line more resembles the heart than brain of a human being; as it is evidently the first place which exhilits life: and though it does not show it by motion, having neither arteries nor $b l o o d$ in this part, yet it is this line which gires life to the lud, to the seed, and to the flower.

There is a curious similitude between the animal and vegetable that should be displayed here, as belonging to this part principally. I have shown that the brain and spinal medulla are the sources of life in the animal, as the line of life is to the vegetalle. I have also mentioner that the muscle and piral wire are the sources of involuntary motion to loth. Now if they are each struck with a quick death, that is not lightning, the irritability in the muscle will remain in both objects for a time atter death; but the animal struck with lightning or the placres, and the vegetable with lightming or a hurd frost, will dive' ly lose that irritability, and immediste decomposition will come on; each body will grow soft, pappy, and katery, putrofaction will suddenly succeed; nay, this is often the ease in both even bofore death. Many have supposed that there might be some volition in plants. But how can that be? What is the cause of will in the human frame? It is alone supported by the connexion of the nerve with the brain; and in motion, that nerve being also fixed on the muscle, by its immedate action proves its oledience to orders sent it from that superior pouer: but there is no nerle in the vegetalle; nor does the muscle (if it could be sub- 
stituted) at all join to the line of life, or form any connexion with it. How then can will be announced or execrited?

There can therefore be no volition in plants, and they can only be a piece of lining mechanism. No person who has seen and dissected a plant killed by electricity, can doubt which is the line of life, since this line is direclly marked from the root to every fibre, and wher completely black in a moment.

I shall now tum to the anind aud regetable muscle. And here the strongest similulide is to be aivcovered; since it is the only part that in lork baings cas be said to move by involuntory motion or wis insita. It is well known that in the human body there are three sorts of motion; the voluntary, the involuntary, and the mixed: but the first two will sarve our purpose here. The first is caused by the will, enforced by the nerve, and executed by the muscle; but the last is spontancous, proceeds from the muscle alone, the cause $u n k i n u n$. It remains often in the muscle after death, ant, after it is divided from the brain, even exercises its full force in this situation. 'The human muscle forms part of the fiesh; it consists of two parts, the wirle (which alone is active), and the thin shining extremity called the tendon. The only purpose of the last is to fix the muscle to the moveable bones, which it does with a force not to be conceived but by feeling it. They are thus fastened in a concentrated manner, in which a greater power is permitted to act, as labours are assisted by ropes in moving weighty bodies; each muscle contracts loth ends towards the centre, which serving as a fixed point, draws the bones with it. The wide part of the muscle is the moving part, and is most curiously formed. The muscles differ in the number of their cases, some animal muscles bave two, or even three; but the vegetable never lnt one. In the human muscle a number of long, soft, leshy fibres are seen inclosing many bundles of hair-like figures, which are the nerves, and which split without end. They appear to me to pass through every part of the muscle, case and all; when the muscle is quite fresh, they seen to move with $l$ ght and moisture if suddenly applied. But $1 \mathrm{am}$ not sure of this, having but once been able to get them fresh enong for this examination. It is difficult to discover how solid the nerves are, since they contract at the end the moment they are cut, and with such instarianeuns effect, that thongh I have divided them with the microscope at my eye, I could not catch a view up the pipe. There is no part of the body which may be properly ealled flesty (and which is in truth the inusele) which is not penetrated in every direction by nervous fibres; their sensibility pervades the whole muscular substance, even its smallest portions; and though they appear not to move themselves, yet they are supposed to twe by some means 
the cause of all voluntary motion to the muscles. Cuvier thinks that they arc the cause of all motion, both voluntary and involuntary; but that certainly cannot be, since the muscles of a plant have the same vis insita, without possessing any nerves. But there may undoubtedly be a sort of vapour, which may pass through the nerves from the brain, and cause a most powerful effect, but still be entirely st parate from that vis insita which is so peculiar to the muscles, that no one who has seen it act both in the human body and vegetalles can confoumd it with any other sort of motion. The hutman muscle is a bundle of vessels: the oil lubrieates them, that they may not be hurt by constant friction: and this is exnetly the case also with the veggetable; but the cases of both muscles are even more wouterful than the hairlike fibril they each contain. The human case appears to be formed of two sorts of vessels; the fibril already described (which also enters into the formation of the case, and runs longitudinally in it), and another sort of vessel which forms a line and space, and passes across the muscle, and gives such a beantiful shining lucid appearance to the muscle caie, and by jis help draws up both vessels. The crossing vessels are alternately filled with a white oily matter, and the spaces between (being perfectly empty) by the help of the nerve which gathers up longitudinaliy, the cross vessels are drawn into rils me above and one below, which running in a forked manner produce that lucid appearance admired by surgeons. When a piece of the muscle case is drawn out, and left to dry, it becomes clear and horny; and if when in thìs state it is hent to and fio very often, the place suells up, and appears of a blueish milky colnur, which I supposed to be caused by the oil given out from the cross vessels. The nerves also (which pass through the muscles) are with this nranagement troken asd dispersed out of their cases; and it is then they are seen running in an undulating manner throurh the oily componad, which, now the vessels are destroyed, retain only a matter much resembling the inpervious skin of the vegetable, only a more oily composition. The regetable muscle-case, like the human, has also the fibril muscle in it: it is formed of straight vessels, replete with oil; but often so lrittle they will not bear to be bent. These vessels are at some distance from each other, and laced up by the spiral wire. Though the figure of each case does not possess a very strong resemblance, yet their effects are the same: they have both the moveaule fibrils within, the oil to lubricate, the case to protect the white oily vesssels also ; no point is wanting to prove that they are intended to produce the same effect, though perhaps set in notion by a different canse. There can be no doubt that light and moisture are the hidden calses of the vegetable motion, since their direct obe- 
a Comparison beiween Animal and Pegu'alle Life. 87

dience when excited by those powens spoaks for itstif. But what is the human cause I leare to better heads than my own. The involuntary motion of the human muscle seems always to take place with a jerk or by impulses. This is exactly the case with the vegetable, nor can they either move again till the relaxation of the muscle has again taken place. It would be curious to ascertain whether the measure is as exact in both as in the veretuble*. In the plant there are two impulses, a long and hort one; the latter, half the length of the former; the first from ball to ball, the second from knot to knot. Both these measures are seen in the Mimost sensitiva; when the whole leaftet dropi, the spiral is moved from ball to ball; but when it is a lorf only, then the spiral moves from knot to knot. When the stamens rub together to throw their dust on the pistil in the mosses, then it is a single impulse; and when a leaf is moved it is the same; aud the misisture it occasions undoes the spiral, and prepares it for a new contraction; and so delicate and sensible is it to each increasing light or decreasing moisture, that each minute almost brings its variation; certainly each passing cloud over the sun, its chanse. $\Lambda$ few words, however, I must add on the unknown canse of the muscular motion. The human muscle lying so near the outward skin, (a cuticle which thongh doubled, nay trebled, is so pierced with pores which must admit much light aud moisture,) would seem to suggest some canse for its motion, of the same nature as the vegetable, ${ }^{7} i d$ not the peculiar sort of cross action in the muscle-crses seem to suggest a difference: and ret there is one cireumstance which is so exactiy contrived respecting the nerves, as it is in the vegctable in the muscles, as to carry some inuression with it: "The sense of touch is supposed to arise from the nernous extremities of the papilla being more numernus, or covered with a thicker or a thinner skin in some places than in otheis, and thus bestowing a grosser or a fin's degrce of feeling to the different parts. Now this is exactly the case with the muscles: they increase their irritability in proportion to their advancement to the olitward cuticle, and as they become more senisible of the effects of the atmosphere.

In all trees and shrubs whose branches live through the winter, and are therefore exposed to severe rhanges, the muscles are comcealed within the wood: but in other plants (rising each year from the earth) they are discovered next the alburnum vessels; and in all very sensitive plants the outrvard cylinders of the rind are few in number and very thin, and the more irritable the muscle the thinner they are. Now there is some analogy herr

* But in the human, I beli ve, it chents on the leigh of the muscle. 


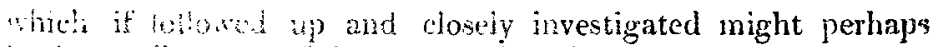
leacl to a di-cerry of the canses of motion.

I suall wow thin to the bone of the animal and wood-of the vesetable, whicli nay from some curious particulars be compared toy her. The first lias a slieleton or system of bones which gives frmosind shape to the fabric, keeps the soft parts in their places, affords fixed points to the organs of motion, and gives them their proper direction, and protects some of the most teuder parts from extemal injury, To connect the hones together, there are ligaments; and to afford smooth surfaces for them to play casily on one another, their extremities are furnished with curlilages or grivtle. The bones consist of an interior, whicis is a speries of honeycomb, and an extericr surface, which has many liyer formed in a particular manner; the last if cut with a very surp knife, and very thin, appears composed of many meandering vessels filled with utoms, which seem to be rather solid, from the clear spaces they show between them; while the honeycomb parts are plates, thick in the middle and meeting in their thin edges. This is also the same as the formation of the large bones of the skull, which increase also towards their centies; but the most cxtraordinary part of the wood is, that the foundation exaclly res.ml'es the thin surface of the bone, and is really composed of diminutsve vessels filled uth atrms: but this is only to be scen in both when excessively nagnified, then they exactiy resemble each other. But the system of wood, though it gives firmness to the fabric, yet obeys mont strictly the laws of the line of life in its shape: it preserves, however, this important part from injury, but is within crery otler soft ingredient, and therefore camot defend it.

In trees and shrubs it serves as some support to the muscle, but in annuals and herbaceous plants the muscle changes its place, and is at the exterial part of the wood. It camnot be said to afford a fixed point for the organs of motion; for it is the gristle which does this, which forms the balls round which the spiral winds itself, and which covers the ends of the wood in such a manner as to enable them to slip over or into each oller, like a cup and ball. I never saw the knee or elbow of a human skeleton that it did not remind me of a Galium, Selene, or some of the stems of those plants which suell at the joint. It is a sort of gristle which serves this purpose and sheathes the wood, a kind of thi $k$ matter, which performs, in its solid or liquid state, many important finctions in the vegetable oconomy, and makes a part, I doubt not, of that resinous compound Dr. Thomson discovered in the wood.

But how curious it would be to possess and be able to examine that liquid which performs that extraordinary office of clearing 
clearing the way through the hard wood for the buds; probably it might serve as a good comparison, to the gastric juice; for great must be its dissolving fowers. When the bud is first formed on the line of life in the root, aus runs up to that part from which it is to start and make its way to the bark, the wood opens it a passage; and this is apparently done, eveu through iron wood, by a lignid which no sooner torches the fibres, than they divide and bend, and thus make a sort of covered u'ay for the but. That the lud passes from the interior no one can, I think, $d: n y$, who examines a tree after it has been barked: at every time of the vear, but particularly in the autumn, a quantity of buds may be seen running from the line of life, to fix themselves in the bark. This is merely the embryo of the bud, or empty seed-vessel, with tie nectareous passages and the corolla, all rolled up together into a little ball. These, when they start from the line of life, possess a juice of a peculiar kind which preceles them, and arranges the wood-ressels a s it passes, $n$ ling them all bend fiom it thus (O): so that there is actually a large space loctween the lud and the wood filled up with sapjelly: nor is it possibie the bud can be even touched, much more injured; since this hollow space is left for it till it reaches its scales, already prepared in the bark for its reception. There is not, perhaps, any of the contrivances of Nature more beautiful than this, or which has been so strangely misunderstood: if the bud had had to force its way, it would have been destroyed. In following the process, it is but cutting away the wood near where there are luds; as you approach one it becomes softer and softer, at last the liquid is discovered, and in the midst of it the litlle delicate embryo, lying in its bath or jelly-case, while a covered way near an inch before it is already prepared for its advancement. As it approackes the bark, its inclosure or cradle is ready for it, with all the conveniences selected for its preservation; and generally a quantity of hairs or points covering the outward scales of the bud, to introduce into the interior, or the ball, all the nourishment the most delicate creature can require; for there are few buds that are not at that time of the year loaded with hairs and instruments. Though I can find no analogy in the human frame for this process, yet I doubt not, if we possessed the liquid, it would assimilate well with the gastic juice. That so delicate, so soft a matter as a bud should pass unhurt through perhaps a foot or two of hard wood (for it must do so in the stem of a very large tree) is really almost miraculous till the methorl is explained. 
Having now described those parts of the human body and vegetable frame, on which their figure, support, strength, and motion depend; we must next examine those juices which are intended to replace the waste of both the machines, and to supply them with new energies. In the animal body are many more sorts of liquin than in the vegetable, because these are so many secretions from the blood: now this is unknown in plants. The animal blood is a rich store of nutritious fluid, fue enough to penetrate its minutest parts, and which constantly circulates through its whole machine: the elements of its composition are furnished by all our food. Now in the vegetable there are but tu'o sorts of liquid that can be said to replace the waste of its substance,-the bark-juice and sap: the first, far from being formed in the body, is inerely collected there from the atmosphere by the hairs, in me of the layers of the leaf, from which place it runs to the inner bark-vessels. It has no circulation like the blood; nor is it formed by the tood, but taken in when separate, and mixed in the pabulum of the leaf. The bark-juices are so far from being capable of circulating, that their tendency to $\mathrm{co-}$ agulute is such, that the bark is full of large species of matter escaped from its liquid state; and even in the vessels of the inner bark (if it was not for their peculiur construction) it would never retain its liquid form, since it is forced through apertures not half the size of the vessels in which it runs; and this impetus, by increasing the violence of the action, tends to its fuidity. The sap is, however, better adapted to play the part of the blood, were not a cinculating medium totally unfit and unsuited to the vegetalle form. A leing increasing at each of its numerous extremities, receiving its blood from another body, and that blood coagulating into a jelly by rest and suspension, before it can form its compound, - can such a make be compatible with a constant circulation of blood? which caunot stop without destroying life. The proving that the sap-juices do not circulate is of the greatest conseguence: if they circulate, and all the juices that should (when they arrive at the extremities) instead of forming the new shoot, rin down again through the bark, - how is the new shoot to be completer? since all that matter whieh was to form it is employed in returning through the bark, leaving the only part which at that time required support and moisture. Is it not more natural to suppose that the juices (as they always become a jelly before they are wood) are arrested to be converted into that matter, and then complete their change? The idea of circulation is draw'n from the comparison of animal life, just only in a few instances, misleading in almost every other. Is there not a great difference between an animal which grows not at its extremitiss, but which after the first few years ceases to increase,

and 
and one which increases every season at every joint, whose juices are independent of itself, and taken from arother, and may naturally be supposed, therefore, to draw up only that liguid which is necessary for that incrense? But if there were a circulating law estahlished by Nature for the sap, it would most probably be a triversol lat, general to all plants: What then would become of thone tress and shrubs which lose their bark in the winter? whore veseis are supuosed by some botanists to convey the sap? If they reniain, they wonld be donbiy conspicuons, when the rest harl departed; and they are certainly not to be found. A trining picce of the green bark is discovered in the winter, and the rest of the space $i$ enpty, and the inner bark vessels are gruerally deprived of their juices. How is then the sap to convey its circulation? If we are to assert that the sap descends again after its ascent, we must show in what vessels. If in the wood-vessels? the bark could not hold a tenth part, as I shall show. If in the bark-ressels? then must we discover the anastomoses or joinings of both series of vessels, that is, the communication between the corlical and ligneous cylinders, the meeting of the wood and bark-vesuels. I injecred a work quantity of :ugar of lead into a plant, and sent the German test after it; but no joinings of vessels were to be perceived: they gave the result indeed, hint traced it to the terminations of the woodvessels in each fresh forming twig. This is always the method I pursue when puzaled respecting the terminating rescels, and it rarely fails me. It is often given as a proof, that the sap circulates in trees, instead of flowing up, as, I think, only to form the different productions it has to complete: "that when the fellers and peelers sat about burking, they cominually fiud the young shoot so full of juice as to be ready to pour over, while in the larger shoot, or lower part of the tree, they are almost dry, at least there is a much smaller quantity of liquid; so that the men often exciaim that the sap enters at the ends of the trigs: but this is the rery circumstance that proves the truth of what I ad. varree. It must be recollected that they do not begin to bark till after a quantity of liquid has passed up the tree from the root, loosening the bark all the way from the wood: therefore it is almost at the end of its flowing time when they begin to peel, or it is very difficult to tear off the bark. The liquid is therefore already arrested in the young shoots. Now its arresting is always the time it takes to become jelly, and soon to receive the wood-vessels and complete the shoot. This, therefore, is the cause of the quantity of sap being always found in the young twigs at this time; three weeks sooner the sap would have been discovered in the middle root. I have often drawn a pint from them at this time. 
The quantity of sap always found in the sap-vessels plainly shows their office: if then there were returning sap-vessels, would they not be equally plain and visible, whether in the bark or wood? Besides, excepl the inner-bark vessels, all the cylinders that can convey juices pass either round the tree or in a transierse direction.

I have but ane more argument with which I shall tronble the reader. It is said that the sap aiter mounting to the top of the tree all descends again, and returus though the bark. Now the bark is in summer one-tenth or eighth part of the wood, and preserves in its decrease (as it mounts the tree) nearly the sams ratio. Suppose, therefore, $a$ a to be the bark; and $b b$ the wood; and as the wood was full of sip-vessels, it is not possible to cram them in less than half that space: the ratio $b c$ must, therefore, be added to $a n$, yet not increase its size. This is indeed adding much to a little and making it less. Had Nature intended the sap-vessels or juices to return into the lark, a conspicuous place would have been allotted for them; but they are now sought in vain. It will be remembered that it is at all times the sap is supposcd to circulate when the bark is quite full of its own juices, the sap must indeed then be invisible.

The absorbent vessels are perhaps both in the animal and vegetable one of the most curious parts of their formation. In the human body they are various: those that open their extremities under the different surfaces of the shin are called exhalants-of these the vegetables possess but a few, since they perspire not, and it is only under the first cuticle of the leaf they are discovered: but there are other absorbent vessels which take in from the atmosphere (even in the human frame) many juices and gases favourable to health, and which. I doubt not increase the nourishment of the body; and though they are not near so numerous as the hairs of vegetables (which are of such a variety of kinds), yet they so increase with the vigutur of the body, and in hard-working people, that I doubt not they are intended to supply much nutriment. In the vegetable it is well known that they do so, and that they have absorbent vessels leading to each hair, to throw the matter thus acquired into the nourishing vessels; and probably they would not increase under such existing circumstances in the human body, but for some such purpose. I doubt not but that those who eradicate hairs, from the silly notion of beautifying their Maker's work, acquire many disorders in the skin that would never be theirs but for this foolish custom. All hairs arise from two distinct capsules, one within the other, having a certain degree of moisture between them; and the only difference between the human and common vegetable hair is, that the latter has many more valves, and bas frequently 
a spiral within the interior cylinler. The human hair shows not that varicty of shape; three or four sorts are all that arc ever discovered. But in the vegetable there is scarcelv a form possible that is not initater: but these I call instrumints, not hairs, since they miach more resemble the various invented glasses of a laboratory than the simplicity of a hair; to each of these, however, an absorbent vessel is adled to convey the juices thus acquired to their various places of destination; while those vessels in the human body are thin pellucid cylinders arising from the various surfaces of the skin, and runing to a common duct caller the thoracic duct. They are of two kinds, the hymphatics and the lacteals. The first the vegetables possess, but not the last. The lymphatics take up the colourless fluid called lymph (whonce they have received their name), and convey it from all the parts of the body to the same point. Thus the parts of the blood, which either from their thin oily or nutritue qualities had been separated from the red blood or circulating mass and thrown out by the exhaling arteries, are absorbed after having performed their various uses, and are again rontucted by the lymplaties into the circulation. But the vegetable having no secretions from the blood, the lymphaties receje from the absorbent vessels those juices introduced from the atmosphere by particular hairs, and which are partly secreted in the giands till wanted. The rest (after performing their various purposes) are carricd into the nourivhing or sap-ressels. But in one point of resemblance both ayree; - -absorption in both bodie: helps to remove those injuries which happen to the frame by accidents. If a tumour proceed from a blow or cut, the absorbents will soon begin to act: a fluid poured from its ruptured vessels will be aboorbed by its lymphatics and carried again into circulation. The hlack or green spot which is left will disappear, and be taken up in both ; fresh supplies of wholesome nourishmont are brought from every part to recruit the bad flew or wool that has leen injurel: and in the plant, so great is the haste made to remedy the defect of this kitud, that it rarely hapjens that a wound is made without such a quantity of nutriment being sent to the part that it generally finishes by baing a nursery for new buls. The absorbents of both beings are full of valves; and as to the glands which secrete the oil and other matters, they are certainly in the regetable as well as the human form, though not so nunierous: the two nectaries of the flower are of this kind. Some excretory ducts also plants must passess; since much matter is conveyed away that would otherwise impede the flow of the sap : for when the new wood is formed, all the old divisions of the piece which had been before lark, disappear quickly, but not so haitily as not to show it is drawn off by degrees by some vessels appripriated for the 
purpose. The broken wood also is in the same predicament, and equally weil managed.

The analogy between the animal and regetable foetus, in respect to their prolicction, nutriment, and oxygenation, is indeed very striking and forcible.

The cvum in the female is discovered at an early period in the virgin state, as is the seed of the tree; and like that, many years pass before the tree arrives at its proper maturity; but they both attain tlat point of perfection at an earlier period in warm countries than in coll. The ovum in the female resembles a bunch of grafes fastened as they are to the umbilieal cord; and when the seed is first formed in the side roots, it is an apparent gross powder, which soon becomes regular balls, and which tied to the line of life, may well be likened to grapes also;-but in one respect they evidently differ. The ovum mones not till after impregnation has taken place; whereas the seed has travelled far and gone almost all its joumey, before it receives the powder of the stamen.

Mirbel says, the vessels in the style unite with those in the peduncle and form the umbilical cord. But Mirbel was not aware that the seed rising from the root had already received (from the first monent of its existence) its umbilical cord (which is indeed its life), when it is fixed in the flower (at the time he alludes to), a long season after its real birth; it then first runs up the interior of the style (which had till then been empty) and increases greatly; when the seed is to be impregnated it swells, and serves as the vehicle to receive the pollen, which soon dissolving in the sweet juices of the line of life, runs down again to each seed, which it touches; when the heart is directly filled up, and the seminal leaves (the lungs of the embryo) proceeding from the interior cavity under the heart, begin to grow.

In the first months of pregnancy the involucra bear a larg proportion to their contents, but afterwards this proportion is reversed. This is also the case with the seed, which evidently changes in this respect, though much quicker than the foetus. The flucenta (which is the medium through which the blood is conveved from the mother to the foetns) is a soft spongy substance like a cake, closely aulhering to the imer surface of the womb; and the arteries of the uterus discharge their contents into this substance of the cake, and thus form the umbilical cord which is to nourish the child. Now this is most exactly imitated in the seed, escept in the last cirrumstance, where another vessel called the nourishing ressel supplies the place of the umbilical cord, in rested to drfing nutriment to the embryo: since there is a broad spongy nistance on the interior surface of the seed, exactly resembling a cake; and before the seed is divided from its 


\section{a Comparison between Animal and Vegetalle Life.}

mother tree, a certain set of veins arising in the lronch from which the seed procegls, and passing throwgh the cover into the interior, is thorouglily filled with a proper ingut, to be used as soon as the division takes place: the seed is then divided from the tree, and the vein closed, which has in the moan time anread

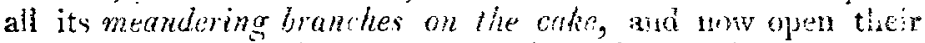
tiny month to produce (with tire joint juices of that sponsy matter) the sort of mitky fuit to nourish the young plant, till the root is formed for the purpore. But the sient has one at vantage unkwown to the foetus: "if at the first shooting of the root it is destroyed, the catse aguin receives the last juices remaining in the nourishing vessels, and forms with its assistance milk suthcient to supply the young one with support till tie growth of the root is renewed." It smay however be said, thas the child is not exposed to a similar disaster, and recuures not therefore such a remedy. This exact imitation of the foetus with the embryo shows that I was right in persisting that the ceminal leaves had nothing to do in nourishing the plant, and were mercly formed to protect the embryo when leaving its $\mathrm{e}_{\mathrm{x}}$ terior cover, and to serve as lungs to the young plant; and that, so far from bestowing nutriment, it required more itself than any other part. I showed this before I knew how the human fotus was mantaged in this respect, and could not therefore be misled by the analogy, which is but too often the case when the kaowledge of human anatomy precedes the dissection of botanical objects. The different covers also of the seed may be compared to the true and spongy chorion; the last is oparne and thick like the white cover of the seed, and the interior clozr, as is the first envelope of the young one, while the heart of the seed first floats in a liquor that may well be compared to the liquor amnit. It is curious that in the latter monthy of pregnancy the spongy chorion becomes gradually thinner and rore connected with the true chorion, which is also the case with the stony fruit and seed. The seed is so easily divided from the mother plant, is obliged to receive that assistance from the cover of its sect the child receives from its mother, and which nutriment the seed took in from its parent plant long as it preserved its hold. The innumerable open-mouthed vessels in the outwand exterior of its case, take in both juices and grases, to be seen flowing into the interior and changing constantly. It is truly astonishing to eee the excessive assistance of this sort the seed receives daily before it is again placed in the ground, and before it forms its radicle: in opening one seed ach day, I have rarely found is without gome new vessels running from the exterior. The seed is of course infuitely quicter in farming than the feetus; for 
scarcely a fortnight elapses after the impregnation of the secd, before all the important parts that can precede maturity are completed.

There are some curious changes in the form of a child before it breathes, and there is also a most curious difference in the seminal leaves in a plant when compared with other plants. They have no spiral wire, and of course no motion, and no midrib or side-ribs: this is very conspicuous in the Mimosa sensitiva, since it is the only part that does not move if touched. It was one of the proofs that ellabled me to ascertain that the spiral wire was the real muscle of the plant.

There is little resemblance between the lungs of a human being and the leaves of trees - nevertheless they perform for each being the same office; and yet it is difficult to draw a comparison between them. The himan lings fill the greater part of the cavity of the breast ; they are of a soft spongy texture, and are divided into two lobes, which are separated from each other by the inediastinum, and externally covered by a production of the plcura : each of these is divided into two or three lesser lobes, are commonly three in the right and two in the left side of the cavity. There are two series of arteries which carry blood tr. the lungs, and it is the expotition of this bleod on the surface which chatges its tint from a darker colour to a lighter red. The pulmonary artery and veins are not intended for the mutriment of the lings; but the blood in its passage through them is destined to undergo those changes, and hecome forid by a greater mixture of oxygen. Respiration constitutes one of those funetions which are properly termed vital, as being essential to life: it consists of an alternate contraction and dilatation of the thorax, by first inspiring air into the lung,s, and then expelling it from them 'y exspiration. When an animal has once breathed, it is easy to see how the motion may be continued; but what occasioned the first inspiration is not so easy to discover.

Now the difference to be discovered in the lungs of plants is, that they have little inspiration of air except in water-plants,-but most of the oxygen given out is taken in as water, then decomposel; the hydrogen drawn off, and secreted for the seeds, while the oxygen is again given out to the amosphere to purify and iniigoralc $i \iota$. The two upper cuticles of the leaf yield oxygen, the under cuticle takes in carlonic acid gas in the night, which is quickly converted into a purer air as soon as the sun has power sufficient in the morning, and again returned to the pullic stock. Many plants fold their leaves at night; but the atmosphere loses not, since they give no gas at that time, but the ${ }^{2}$ gres and hairs of their leaves are taking in quantities of 
water; nor do they open them in the morning till the sun has power enough to decompose the liquid. Then what clonds of apparent smoke pour from every hedge or tree, filing the morning air with vapour! I doubt not also that much of this pure gas is given out when the leaf forms its pals'n, from the decomposition of the several juices the hairs ba we colle ted to compose this new compouni, in wlich all vital air is banished. Nor is it improbable that the hairy points may help in a bright day to decomr..... and set at liberty the cxygen of the bubbles of water without turther process, as it certainly occurs to the green matter or fresh water conferva in Priestley's experiment, which is owing to the fine points of both. As those insects which have spiracula or breathing apertures, as suasps and $f_{i} \mathrm{~s}$, are immediately suffocated if oil be poured on them, so the leaves (if a brush is merely passed over them, giving then a simple varnish of oil) flirectly grow black and die. The confining the air within them, and stopping all their natural functions, is sufficient to kill them. That some thick flowers serve as respiratory organs as well as the leaves, I have no doubt, since there are in most of them open air-vessels for the purpose: when without leaves, therefore, the petals serve as lungs to the plant, as they always have that circular vessel alternately holding air or water surrounding them.

A tree in the winter will bear the closest confuement; but the moment its leaves appear and open, if it has not plenty of air it dies : hence the number killed in a hot day in spring. Nothing can be more different than the skin of a human being and the cuticle of a plant: in one point only they agree-that they have both many layers. The human cutis which covers the Hesh is composed of filres closely compacted, through which the ends of the nerves appear which give out perspiration, and on which skin innutnerable papillce are discovered coiled up, or spreal out, and which seem to be calculated to receive the impressions of the touch, being the most in ytiantity where the sense of feeling is the most debicate, as in the palms of the hauds and the fingers. This skin, which will stretch to any extent and contrat again, has been known in cases of dropsy to stretch a foot or two, and reduce itself when the water was discharged. It is always of a white colour, while the matter which covers it and lies between the eutis and epidermis is that which gives the tint to the fair, brown, or black person. This is called the rete mucostum; it is a mucous substance which may be dissolved in water, and which in negroes is quite black. Next to this is the epidermis or scarf skin. It is a fine transparent insensille pellicle, destitute of nerves and blood-vessels, and every where covering the true skin, which invests the body. It is in reality composed of several laminæ or scales, and is full of pores, through which the perspiration passes

Vol. 46. No. 208. August 1815. 
from the cuds of the nerves on the cuts. The use of this last skin is to protect the delicate nervous fibres which stand out from the true skin: it increases by pressure; and the more scales are added, the less that nervous sensilility is felt. This is the reason that hard-working people can put their hands in the fire or in extreme hot water, without being sensible of pain: the more this skin is increased, the less feeling they possess.

As the plant has no nerves, it can have no feeling; and as it has no perspiration, it can have no pore. 'The marks seen in the skin are mercly the effect of the opening of the balis in the second and third cuticle, which contain first the water and then the oxygen. The first cuticle is perfectly impervious to water, and completely like gold-beater's skin, without figrure. Air, however, passes it freely: but for this skin, how could the water be retained to be decomposed?

I have said that there is no perspiration in plants; indeed it was perfectly imposizle that the vegetables could decompose water to give out oxygen, and at the same time perspire such quantities-and yet have juices enough left to support the plant. It seems to me that the inconparable Mirbel almost owned his unbelief long ago:- that those bubbles taken for watir have proved to be instruments of varions kinds and forms, an:! show themselves to be undoubtedly the most beautilul and complicated part of the vegetable arrangement. As in the animal body there are such a variety of secretions from the blood, which require an immense merlianism, not suited to the general simplicity of the form of a plant, so in its stead Nature has contrived that it should receive from the atmosphere, by means of these instruments or hairs, all the juices necessary to the vegetable, in lieu of forming them by secrction: but they are not received in their perfect state, but often alter greatly between their entering the valve and fowing into the plant: nay, I have frequently known two liriuids enter the hairs and secrete themselves between the two different valves; then meeting explode, and compose a third juice, and thus form by chemical afhinity the matter which the plant requires. This is really the most beautiful part of the study of plants; and to chemists would (I should conceive) serve as an elucidation to many points, if they would condescend to try them. Even oil is received by the hairs in a sort of vapour, and only becomes oil when it reaches the first liquid; and they both enter the third vilye purified and completed. I have watched the various liquids innumerable times; nay, 1 might truly say, for months together - their manner of filling and emptying their hairs-the variety of their juices-the curious changes made in them-and the getting rid of the obnoxious part by means of the outward cuicle of the hair, and then sending down 
into the plant that which is completed. 'This account would fill volumes instead of a few pages, if thorough justice were done to so beautiful and inimitable a contrivance. But what pen or what tongue can properly dispiay the works of Him who can conceive and form such productions!

Between the skin or cutis, and the muscles or flesh, there is interposed a loose oily substance. It is continued without interruption over the whole exterior of the muscles, and is called the cellular sul,tance, filling up their depressions, and affording a smonth and regular surface for the skin to lie upon. This substance is composed of a cellular texture and fat: the latter is fluid in the body, and is deposited in cells in the former for facilitating muscular motion; and though found in the greatest quantity in the cells of the membrane filling up the space between the most external muscles of the skin, yet it may be met with in most other parts of the body. Just so is the vegetalle pith, composed of a cellular texture, filling up the depressions the line of life frequently makes in its curious undulations, which every other part is obliged to follow: the only difference is, that it is not placed in the same situation, but owing to the softness of its texture it admits of the wood in very vigorous trees increasing both ways, and allowing also of the yearly swelling of the line of life, when the bud passes up its cylinders, from the root upwards. The pith serves also to contain water, instead of fat; and by its quick growth supplies each vacancy till the wood is able to fill its situation.

Having now brought forward (though in so imperfect a sketch) each different ingredient possible to compare together in the human form and vegetalle frame; let me now see what results may lie draun from the comparisor. First it proves, I think, that the vegetable frame is a mere muscular creature, having life only, but no sensation-no sensibility, but possessing alone the property of the muscles (irrilability). The comparison proves also a matter of great consequence to the vegetable, which is, that as the only part in the human body possessing self-motion (independent of all other parts) or vis insita is the muscle, so the only part in the plant possessing the sume motion or vis insita is the spiral wire: that part therefore must be the muscle of the vegetable, as I have long ago endeavoured to show by other arguments, as I never yet could find motion in any part that did not possess the spiral wire, and that the motion was always in proportion to the quantity or peculiar formation of the muscle: as the tendril of the vine aduirably shows, which is composed of little else. We learn also that there are no secretions either from bark-juice or sap, but that Nature supplies them in the vegetable in a different way, drawing G 2 them 
them from the atmosphere, and then completing them in the hairs by chenical affinity.

Most of the accounts descriptive of the human body are selected from our best surgical books; Hunter, Haller, Monro, Burk, and Cooper. I have since, however, regretted I did not form the comparison between the insect or amphilia tribe and the vegetable, as, certainly approaching nearer togetter, they would admit a more perfect similitude; but I was fearful the dissection of the insect tribe would not be sufficiently known, to interest;or the lungs of the frog's foetus are so like the part of the lerf which serves as lungs to the plant; and the admirable manner in which the muscles of the snail display themselves, so well discriminate its different parts of tendon, muscle or moving part, and the nerve to which it is attached, as to take away all obseu rity from the subject; which is however with the least attention plain enough. The inimitable Swammerdam, who studied the muscles most deeply, thinks their internal motion may arise from a similar cause with those of the vegetable.

$$
\begin{aligned}
& \text { I am, sir, } \\
& \text { Your obliged servant, }
\end{aligned}
$$

Agres IbBetson.

XXII. On Citric Acid. By Samuel Parkes, F.L.S.M.G.S.
$g^{\circ} c$.

[Concluded from p.60.]

The juice of several other fruits, besides those of limes and lemons, will furnish the citric acid, either alone or mixed with other vegetable acids. Thus the cranberry (the vaccinizm oxycoccus of Linnæus), the red whortleberry (vaccinium vitis idcea), the birds-cherry (prunus padust), the berry of the nightsharle (solanum dulcamarat), and the hep, or friit of the wild briar (cynoslatus vel rosa canina $\$$ ), yield chiefly the citric acid |, while in the red gooseberry (ribes grossularia), the garden currant

* As the fruit of this sinub is laroly employed in most families, some persons nay be glad to be informed that these berries may be preserved perfect for several years, merely by dryiug thein a little in the sum, and then stopping them closely in dry bottles.

+ Although this fruit is of itself nauseous, yet when bruised and infused in wine or braudy, it gives $\mathrm{it}$ an agreeable flavour.

f Linnous says that an infusion of the young twigs of this plant is an admirable medicine in acute rhematism.

$\$$ The pulp of these bertics, heat up with sugar, makes the conserve of heps of the pharmacopocia. Mixed vith wine it is an acceptable treat in the north of Europe.

If Westrumb has shown that the juice of the common cherry contains scarcely any other acid than the citric. 